\title{
CORRELATION BETWEEN HELICOBACTER PYLORI INFECTION AND RISK OF ESOPHAGOGASTRIC VARICEAL BLEEDING IN LIVER CIRRHOSIS
}

\author{
By \\ Mohammed Ismael Abdallah, Fathy Ghamry Abd El-Razek, El-Sayed \\ El-Meghawry El-Sayed and Tarek Mustafa Emran*
}

Internal Medicine, and Clinical Pathology* departments, Al-Azhar Faculty of Medicine

Mobile: (+20) 01067752719, E-mail: draboabderazeek@ gmail.com

\begin{abstract}
Background: Bleeding from esophageal and gastric varices is a fatal event in patients with liver cirrhosis and portal hypertension.

Objective: Evaluation the correlation between Helicobacter Pylori infection and risk of esophagogastric variceal bleeding in liver cirrhosis.

Patients and Methods: This study was carried out on one hundred (100) patients, suffering from post hepatitic cirrhosis and portal hypertension: fifty (50) of them presented with esophageogastric varices without bleeding selected from patients coming for screening of esophagogastric varices for anti-hepatitis $\mathrm{c}$ virus treatment, and the other fifty (50) presented with acute variceal bleeding. All patients attending to Internal Medicine outpatient's clinic and Internal Medicine Department of Al-Azhar University Hospital at new Damietta during the period from September 2018, to April 2020. All patients were subjected to complete history, clinical assessment, abdominal ultrasonography, upper GIT endoscope and laboratory investigations.

Results: There was a significant relation between H.Pylori infection and the presence of esophagogastric variceal hemorrhage and $\mathrm{H}$. Pylori infection was positive in $92 \%$ of the patients in group II, and $24 \%$ patients was grade II oseophageal varices, $70 \%$ grade III oseophagogastric varices, and 6\% grade IV oseophagogastric varices, There was a statistically significant correlation of increased esophageal varices (grade three) in positive $\mathrm{H}$ pylori in group II, while in group I detection of H.pylori showed $24 \%$ patients were positive, and $76 \%$ patients were negative. Endoscopic examination showed 40 patients without esophagogastric varices (80\%), $8 \%$ patients grade I, $4 \%$ patients grade II, $6 \%$ patients grade III, $2 \%$ patients grade IV, and there was a statistically significant increase on esophageal varices (grade zero) in negative $\mathrm{H}$ pylori in group I.
\end{abstract}

Conclusion: Helicobacter Pylori infection helped in the development of portal hypertensive gastropathy as well as its severity, and increased risk of esophagogastric variceal bleeding in patients with liver cirrhosis. So, eradication and treatment of Helicobacter Pylori in all patients with liver cirrhosis helped to decrease risk of esophagogastric variceal bleeding in these patients.

Keywords: Helicobacter Pylori, portal hypertensive gastropathy, liver cirrhosis and esophagogastric varices.

\section{INTRODUCTION}

Bleeding from esophageal and gastric varices is a fatal event in patients with liver cirrhosis and portal hypertension
(Yoshihiro et al., 2013). Kirchner et al. (2011) reported that there were many studies on relationships between Helicobacter Pylori (H. pylori) infection and peptic ulcer, chronic atrophic gastritis, 
portal hypertensive gastropathy, thrombocytopenia (post-infection antibody production) and hepatic encephalopathy (ammonia production caused by urease activity of $\mathrm{H}$. pylori) in the patients with liver cirrhosis and portal hypertension.

Garcia-Tsao and Bosch (2010) studied the risk factors for bleeding of esophagogastric variceal rupture and showed that the systemic factors include hepatic functional reserve, ascites, concurrent hepato cellular carcinoma (HCC), endotoxemia, and stress. On the other hand, Tajiri et al. (2010) described the local factors including esophagitis, peptic erosion or ulcer, variceal size, alcohol, and use of an NSAID, or anticancer agent also the hemodynamic factors are portal pressure exceeding 12 $\mathrm{mm} \mathrm{Hg}$, and high intravariceal pressure with variceal wall tension (LaPlace equation).

Mitchell and Katelaris (2016) showed that Helicobacter pylori are a microaerophile, a Gram-negative bacillus, resistant to the activity of gastric juice. Sun et al. (2016) reported that H.pylori causes local (limited to the gastric mucous membrane) and general increase of proinflammatory cytokines interleukin (IL)-1, IL-2, IL-4, IL-6, IL-8, IL-10, IL17 , interferon- $\beta$, and tumor necrosis factor- $\alpha$. Also, Joanna et al. (2017) reported that $H$. pylori infection is significantly more frequent among patients with postinflammatory liver cirrhosis related to $\mathrm{HCV}$ or HBV infection than in patients with alcoholic liver cirrhosis or Primary Biliary cirrhosis (PBC).
Raffaele et al. (2016) reported that there is a direct involvement of $\mathrm{H}$. pylori in the development of portal hypertension $(\mathrm{PH})$ in cirrhotic patients has been postulated.

The aim of this work was to evaluate the correlation between Helicobacter Pylori infection and risk of esophagogastric variceal bleeding in liver cirrhosis.

\section{PATIENTS AND METHODS}

This study was carried out on one hundred (100) patients, suffering from post hepatitic cirrhosis and portal hypertension: fifty (50) of them presented with esophageogastric varices without bleeding selected from patients coming for screening of esophagogastric varices for anti-hepatitis c virus treatment, and the other fifty (50) presented with acute variceal bleeding. All patients attending to Internal Medicine outpatient's clinic and Internal Medicine Department of AlAzhar University Hospital at new Damietta at the period from September 2018, to April 2020. They were divided into 2 groups: Group I: 50 patients with esophageogastric varices without bleeding attending to endoscopic screening for antihepatitis c virus treatment. Group II: 50 patients with acute esophageogastric variceal bleeding. All patients were supplied informed consent before participating in this study.

All patients were subjected to full medical history, clinical examination, laboratory investigations: complete blood picture (CBC), liver function tests including serum bilirubin, serum albumin, serum alanine transferase (ALT) and aspartate transferase (AST), alfa feto 
protein ( $\alpha$ feto protein) and Coagulation profile: Prothrompin Time (PT), International Normalized Ratio INR, hepatitis $\mathrm{c}$ virus antibody and renal function tests including serum creatinine and blood urea, and serum pepsinogen was measured as indices of gastric acid secretion. Blood samples were taken after 12 to $14 \mathrm{~h}$ overnight fasting and centrifuged within 30 to $45 \mathrm{~min}$ of collection, Pelvi-abdominal ultrasonography and upper gastrointestinal endoscopy.

Esophageal varices were graded according to their size. Grading classification of I-IV was used: Grade I for varices in the level of mucosa, Grade II for varices smaller than $5 \mathrm{~mm}$ filling less than $1 / 3$ of the oesophageal lumen, Grade III for varices larger than $5 \mathrm{~mm}$ filling more than $1 / 3$ of the oesophageal lumen, Grade IV for varices occupied more than $2 / 3$ of esophageal lumen (Joanna et al., 2017).

The patients presented with acute variceal bleeding were subjected to management according to the management protocol for variceal bleeding, while the patients without bleeding subjected to management according to their condition. Endoscopic variceal ligation (EVL) or endoscopic injection sclerotherapy (EIS) with 5\% ethanolamine oleate were performed for bleeding from esophageal varices. Acute bleeding from gastric fundal varices was treated by endoscopic Histoacryl (n-butyl2-cyanoacrylate $[\mathrm{CA}]$; B. Braun, Melsungen, Germany) glue injection and H. pylori screening Gastric biopsy was obtained for specific diagnosis of $\mathrm{H}$. pylori by pathohistological examination. All patients were screened for $\mathrm{H}$. pylori prevalence using a commercial ELISA kit (anti-H. pylori IgG ELISA) (Joanna et al., 2017). All procedures in this study followed Al-Azhar University Ethical committee regulations, and patient consent was taken from all patients. This work was not financially supported.

\section{Statistical methodology:}

Data were collected, coded, revised and entered to the Statistical Package for the Social Sciences (IBM SPSS) version 20. The data were presented as number and percentages for the qualitative data, mean, standard deviations and ranges for the quantitative data. Independent t-test was used in the comparison between two groups with quantitative data and parametric distribution and Chi-square test was used in the comparison between two groups with qualitative data: $\mathrm{P}<0.05$ was considered Significant (S).

\section{RESULTS}

This study was carried out on one hundred (100) patients with post hepatitis cirrhosis and portal hypertension, Group I: (26 females and 24males), their ages ranged between (68-37 years) with mean $52.54 \pm 9.01$. Group II: (23 females and 27 males), their ages ranged between (69-
46 years) with mean $55.58 \pm 5.89$. In our study there were significant increased esophageal varices (grade three) and intervention made to them (injection sclerotherapy) in group II in comparison to group I, while Portal HTN was increased in all patients in both groups. 
Also, in our study there was a positive correlation of increased esophageal varices (grade three) in positive $\mathrm{H}$ pylori in group II, and there was a positive correlation of increased esophageal varices (grade zero) in negative $\mathrm{H}$ pylori in group I. In this study, there was a significant increased serum level of pepsinogen in group II esophagastric varicose with bleeding in comparison to group I, while there was a positive correlation of incresed pepsinogen, in positive $\mathrm{H}$ pylori patients in group II. There was a positive correlation of decrease pepsinogen, in negative $\mathrm{H}$ pylori in group I (Table 1).

Table (1): Comparison between incidence of H.pylori, serum pepsinogen, portal hypertension and upper endoscopy in both groups

\begin{tabular}{|c|c|c|c|c|c|c|c|}
\hline \multirow{2}{*}{ Para } & \multirow[t]{2}{*}{ Groups } & \multicolumn{2}{|c|}{$\begin{array}{c}\text { Group I } \\
\text { Esophagastric } \\
\text { varicose without } \\
\text { bleeding } \mathrm{N}=50\end{array}$} & \multicolumn{2}{|c|}{$\begin{array}{c}\text { Group II } \\
\text { Esophagastric } \\
\text { varicose with } \\
\text { bleeding } N=50\end{array}$} & \multicolumn{2}{|c|}{ Chi square test } \\
\hline & & No & $\%$ & No & $\%$ & $\mathrm{x} 2$ & $\mathrm{p}$ value \\
\hline \multirow{2}{*}{ H. pylori } & Negative & 38 & $76.0 \%$ & 4 & $8.0 \%$ & \multirow{2}{*}{47.455} & \multirow{2}{*}{$<0.001 \mathrm{~s}$} \\
\hline & Positive & 12 & $24.0 \%$ & 46 & $92.0 \%$ & & \\
\hline \multirow{5}{*}{$\begin{array}{c}\text { Esophageal } \\
\text { Varices } \\
\text { grading }\end{array}$} & Zero & 40 & $80.0 \%$ & 0 & $0.0 \%$ & \multirow{5}{*}{$\begin{array}{c}\mathbf{x}^{\mathbf{2}} \\
79.090\end{array}$} & \multirow{5}{*}{$<0.001$} \\
\hline & One & 4 & $8.0 \%$ & 0 & $0.0 \%$ & & \\
\hline & Two & 2 & $4.0 \%$ & 12 & $24.0 \%$ & & \\
\hline & Three & 3 & $6.0 \%$ & 35 & $70.0 \%$ & & \\
\hline & Four & 1 & $2.0 \%$ & 3 & $6.0 \%$ & & \\
\hline \multirow{3}{*}{$\begin{array}{l}\text { Intervention } \\
\text { made }\end{array}$} & $\begin{array}{l}\text { Band } \\
\text { ligation }\end{array}$ & 3 & $6.0 \%$ & 12 & $24.0 \%$ & \multirow{3}{*}{$\begin{array}{c}\mathbf{x}^{\mathbf{2}} \\
79.278\end{array}$} & \multirow{3}{*}{$<0.001$} \\
\hline & Follow up & 44 & $88.0 \%$ & 0 & $0.0 \%$ & & \\
\hline & $\begin{array}{l}\text { Injection } \\
\text { Sclerother } \\
\text { apy }\end{array}$ & 3 & $6.0 \%$ & 38 & $76.0 \%$ & & \\
\hline Portal HTN & Positive & 50 & $100.0 \%$ & 50 & $100.0 \%$ & 0 & 1 \\
\hline \multirow{2}{*}{ Pepsinogen } & Mean & \multicolumn{2}{|c|}{38.58} & \multicolumn{2}{|c|}{67.30} & t-test & $\mathrm{P}$ value \\
\hline & SD & \multicolumn{2}{|c|}{10.31} & \multicolumn{2}{|c|}{13.84} & -11.768 & $<0.001 \mathrm{~s}$ \\
\hline
\end{tabular}

As regard history of encephalopathy and child classification results showed there was a significant increased history of encephalopathy (grade III) and child classification (class c) in group II in comparison to group I (Table 2). 
Table (2): Comparison between history of encephalopathy and Child classification in both groups

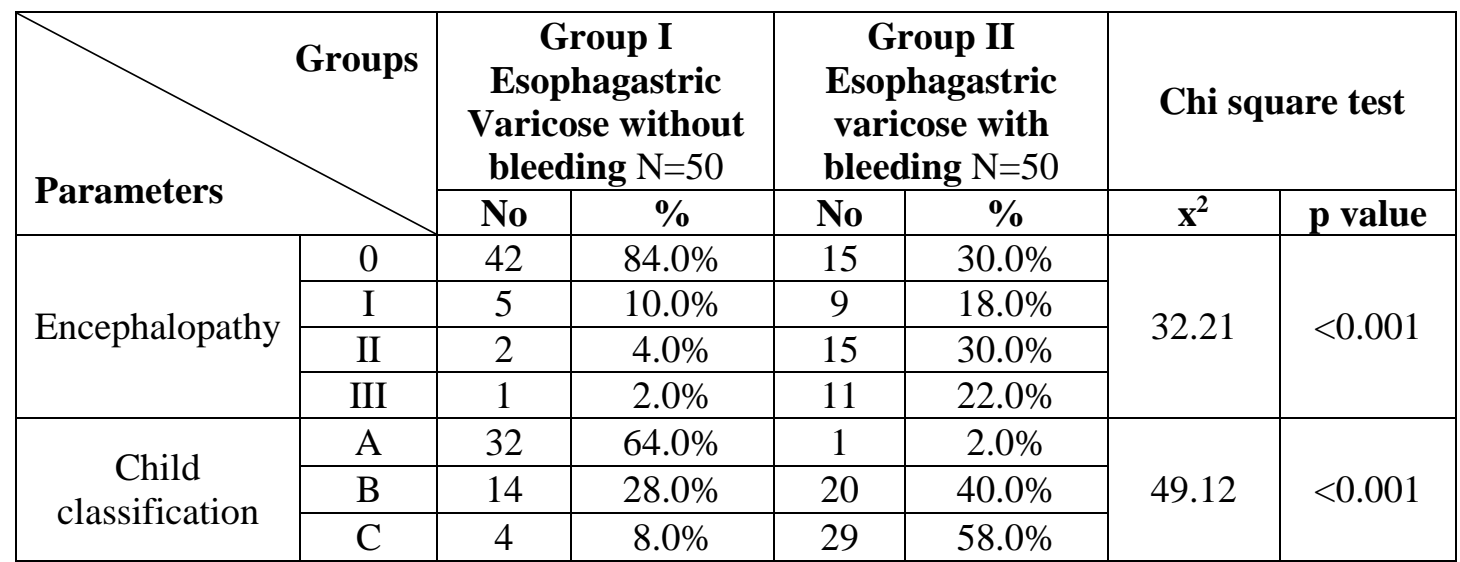

As regard correlation of H.pylori and esophageal varices grading among both groups there was a positive correlation of increased esophageal varices (grade three) in positive $\mathrm{H}$ pylori in group II, and there was a positive correlation of increased esophageal varices (grade zero) in negative $\mathrm{H}$ pylori in group I (Table 3).

Table (3): Correlation of groups as regard H.pylori and esophageal varices grading

\begin{tabular}{|c|c|c|c|c|c|c|c|c|c|c|c|c|c|}
\hline \multirow{3}{*}{\multicolumn{2}{|c|}{ Parameters }} & \multicolumn{6}{|c|}{$\begin{array}{l}\text { H.pylori in Esophagastric varicose } \\
\text { without bleeding } N=50\end{array}$} & \multicolumn{6}{|c|}{$\begin{array}{c}\text { H.pylori in Esophagastric varicose } \\
\text { with bleeding } \mathrm{N}=50\end{array}$} \\
\hline & & \multicolumn{2}{|c|}{ Negative } & \multicolumn{2}{|c|}{ Positive } & \multicolumn{2}{|c|}{ Chi square Test } & \multicolumn{2}{|c|}{ Negative } & \multicolumn{2}{|c|}{ Positive } & \multicolumn{2}{|c|}{ Chi square test } \\
\hline & & No & $\%$ & No & $\%$ & $\mathbf{x}^{2}$ & p value & No & $\%$ & No & $\%$ & $\mathrm{x}^{2}$ & p value \\
\hline \multirow{5}{*}{$\begin{array}{l}\text { Esophageal } \\
\text { Varices } \\
\text { grading }\end{array}$} & Zero & 37 & $97.4 \%$ & 3 & $25.0 \%$ & \multirow{5}{*}{30.674} & \multirow{5}{*}{$<0.001$} & 0 & $0.0 \%$ & 0 & $0.0 \%$ & \multirow{5}{*}{13.768} & \multirow{5}{*}{0.001} \\
\hline & One & 1 & $2.6 \%$ & 3 & $25.0 \%$ & & & 0 & $0.0 \%$ & 0 & $0.0 \%$ & & \\
\hline & Two & 0 & $0.0 \%$ & 2 & $16.7 \%$ & & & 4 & $100.0 \%$ & 8 & $17.4 \%$ & & \\
\hline & Three & 0 & $0.0 \%$ & 3 & $25.0 \%$ & & & 0 & $0.0 \%$ & 35 & $76.1 \%$ & & \\
\hline & Four & 0 & $0.0 \%$ & 1 & $8.3 \%$ & & & 0 & $0.0 \%$ & 3 & $6.5 \%$ & & \\
\hline
\end{tabular}

\section{DISCUSSION}

H.pylori infection is significantly more frequent among patients with post inflammatory liver cirrhosis related to $\mathrm{HCV}$ or HBV infection than in patients with alcoholic liver cirrhosis or primary biliary cirrhosis (PBC) (Kumar et al. 2010).

In this study, there was no statistical significant difference as regards sex, but there was a statistically significant increased age in group II in comparison to group I. In agreement with our results, Safwat et al. (2015) documented that there is a significant relation between the age of the cirrhotic patients and the development of portal hypertensive gastropathy (PHG) and esophagogastric varices but no relation between the sex of the patients and development of PHG.

There was a statistically significant increased moderate liver cirrhosis in group II in comparison to group I. There was a statistically significant increase child classification (class C) in group II in comparison to group I. In agreement with our results, Feng et al. (2014) reported that $H$. pylori infection increases serum ammonia levels which may be responsible for the mental disorders associated with hepatic encephalopathy. 
In this study, there was a statistically significant increased serum level of pepsinogen in group II esophagastric varicose with bleeding in comparison to group I esophagastric varicose without bleeding. There was a positive correlation of increased pepsinogen in positive $\mathrm{H}$ pylori patients in group II, and positive correlation of decrease pepsinogen in negative $\mathrm{H}$ pylori in group I. Sathar et al. (2014) showed that serum pepsinogen (PG) is a biochemical index of gastric acid secretory capacity, pepsinogen level reflects acid secretion of the gastric corpus.

In contrast to our findings, Yoshihiro et al. (2013) examined pepsinogen as a biomarker, and found that gastric acid secretion was lower in the $H$. pylori positive patients, and that eradication of H. pylori resulted in recovery of gastric acid secretion. They suggested that the chronic atrophic gastritis progressed because of chronic $\mathrm{H}$. pylori infection, and the total serum pepsinogen level decreased.

Rockey (2019) showed that portal hypertension most commonly develops in the setting of chronic liver injury with cirrhosis. Bruce (2018) reported that the three primary complications of portal hypertension are gastroesophageal varices with hemorrhage, ascites, and hypersplenism.

In this study, there were statistically significant increased esophageal varices (grade three) and intervention made to them (injection sclerotherapy) in group II in comparison to group I, while portal HTN increased in all patients in both groups. Also, there was a positive correlation of increased esophageal varices (grade three) in positive $\mathrm{H}$ pylori in group II, and positive correlation of increased esophageal varices (grade zero) in negative $\mathrm{H}$ pylori in group $\mathrm{I}$.

This was in accordance with Abbasi et al. (2011) who observed that the grade of esophageal varices had significant relation with portal hypertensive gastropathy (PHG) the severity of PHG increased with the grade of esophageal varices. On the other hand, Joanna et al. (2017) reported high incidence of $\mathrm{H}$. pylori infection among patients with severe inflammatory lesions of the gastric mucosa.

In this study, there was a statistically significant increased incidence of $\mathrm{H}$. pylori in group II in comparison to group I. In agreement with our study, El-Masry et al. (2010) reported that the incidence of H. pylori infection among patients with liver cirrhosis and those infected with $\mathrm{HCV}$ increases with more pronounced liver failure. Also, Raffaele et al. (2016) argue for high probability of the influence of $\mathrm{H}$. pylori infection on increase of portal hypertension, which is one of the most important causes of the development of esophageal varices. In addition, Yoshihiro et al. (2013) reported that, in gastric mucosa of patients with liver cirrhosis and portal hypertension, there is portal hypertensive gastropathy including a decrease in blood flow, prostaglandin E2 synthesis, and mucus secretion, Consequently, gastric mucosa weakens and tends to be easily injured, when inflammation from $\mathrm{H}$. pylori infection is added to the surface mucosa of varices, mucosal breaks can occur easily and become a trigger for variceal bleeding. They showed that H. pylori infection has a protective effect and not a promotive 
effect on variceal bleeding, through the induction of atrophic gastritis and hypoacidity.

In this study, there was a positive correlation of increased esophageal varices (grade three) in positive $\mathrm{H}$ pylori in group II, and positive correlation of increased esophageal varices (grade zero) in negative $\mathrm{H}$ pylori in group $\mathrm{I}$. This was in accordance with Waluga et al. (2015) who reported that esophageal varices occur more often in the group of patients infected with $\mathrm{H}$. pylori. Moreover, the correlation between the stage of varices and incidence of $\mathrm{H}$. pylori infection may point to significant direct effect of these bacteria on liver function. In addition, Safwat et al. (2015) showed that prevalence of H.Pylori infection was higher in patients with PHG in comparison to patients without (PHG).

\section{CONCLUSION}

Helicobacter Pylori infection helped in the development of portal hypertensive gastropathy as well as its severity, and increased risk of esophagogastric variceal bleeding in patients with liver cirrhosis.

\section{REFERENCES}

1. Abbasi A., Bhutto AR., Butt N., Munir $S$ and Dhillo AK. (2011): Frequency of portal hypertensive gastropathy and its relationship with biochemical, haematological and endoscopic features in cirrhosis. J Coll Physicians Surg Pak., 21: 723-726.

2. Bruce R. (2018): Gastroenterology and Hepatology. In: Harrison Internal Medicine, Pbl by McGraw-Hill Education, United States, 20: 2560-2579.

3. El-Masry S, El-Shahat M, Badra G, Aboel-Nour MF and Lotfy M. (2010):
Helicobacter pylori and hepatitis $\mathrm{C}$ virus coinfection in Egyptian patients. J Glob Infect Dis., 1: 4-9.

4. Feng H, Zhou $X$ and Zhang G. (2014): Association between cirrhosis and Helicobacter pylori infection: a metaanalysis. E ur J Gastroenterol Hepatol., 26: 1309-1319.

5. Garcia-Tsao $G$ and Bosch J. (2010): Management of varices and variceal hemorrhage in cirrhosis. N. Engl. J. Med., 32: 823-862.

6. Joanna P, Magda L, Alicja K, Tadeusz L and Robert F. (2017): Helicobacter pylori infection among patients with liver cirrhosis. European Journal of Gastroenterology \& Hepatology, 17: 691699.

7. Kirchner GI, Beil W, S. Bleck J, Manns $M$ and Wagner S. (2011): Prevalence of Helicobacter pylori and occurrence of gastroduodenal lesions in patients with liver cirrhosis. Int. J. Clin. Exp. Med., 4: 26-31.

8. Kumar A, Mishra S, Sharma P, Sharma B. and Sarin S. (2010): Clinical, laboratory, and hemodynamic parameters in portal hypertensive gastropathy: a study of 254 cirrhotics. Journal of clinical gastroenterology, 44: 294-300.

9. Mitchell $H$ and Katelaris P. (2016): clinical impacts and current clinical management of Helicobacter pylori infection. Med J Aust., 10: 376-380.

10. Raffaele L, Giuseppe $L$, Sonia $C$, Andrea I, Floriana G, Michele B, Mariabeatrice P, Enzo I and Alfredo Di Leo. (2016): Helicobacter pylori, liver cirrhosis, and portal hypertension: an updated appraisal. Immunopharmacology and Immunotoxicology, 38: 408-416.

11. Rockey D C. (2019): Portal hypertensive gastropathy, Am J Gastroenterol., 22: 875-887. 
12. Safwat E., Hussein $H$ A. and Hakim $S$ A. (2015): Helicobacter pylori in Egyptian patients with $\mathrm{HCV}$-related liver cirrhosis and portal hypertensive gastropathy: Prevalence and relation to disease severity. Life Science Journal, 12: $15-28$.

13. Sathar SA, Kunnathuparambil SG, Sreesh S, Narayanan $P$ and Vinayakumar KR. (2014): Helicobacter pylori infection in patients with liver cirrhosis: prevalence and association with portal hypertensive gastropathy. Ann Gastroenterol., 1:48-52.

14. Sun X, Xu Y, Wang L, Zhang F, Zhang J, Fu X, Ximei Fu, Tao Jing and Jian Han. (2016): Association between TNFA gene polymorphisms and Helicobacter pylori infection: a meta-analysis. PLoS One.,1: 41-47.
15. Tajiri T., Yoshida H., Obara K., Onji M., Kage M., Kitano S., Kokudo N., Kokubu S., Sakaida I and Sata M. (2010): General rules for recording endoscopic findings of esophagogastric varices. Digestive Endoscopy, 22: 1-9.

16. Waluga M, Kukla M, Żorniak M, Bacik A and Kotulski R. (2015): From the stomach to other organs: Helicobacter pylori and the liver. World J Hepatol., 18: 2136-2146.

17. Yoshihiro S, Kazuhiko O, Atsushi T, Masafumi K, Tsuyoshi H, Hiroto I, Keigo E and Osamu T. (2013): Effect of Helicobacter pylori infection on esophagogastric variceal bleeding in patients with liver cirrhosis and portal hypertension. Journal of Gastroenterology and Hepatology, 28: 1444-1449. 


\section{العلاقة بين الإصسابة ببكتريا المعدة الحلزونية كمؤشر خطورة

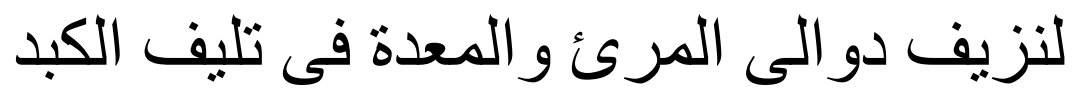

محمد إسماعيل عبدالله، فتحى غمرى عبدالرازق، السيد المغاورى السيد، طارق

$$
\text { مصطقى عمران }
$$

قسم الباطنة العامة والباثولوجيا الإعلينيكية**، كلية طب الأزهر

Mobile: (+20) 01067752719, E-mail: draboabderazeek@ gmail.com

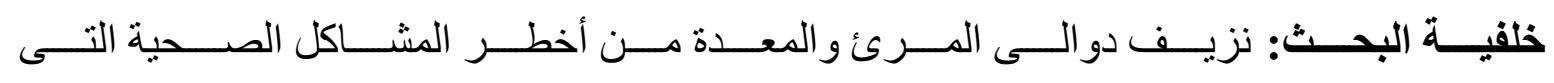
تو اجه المرضى متليفى الكبد المصابين بزيادة ضغط الوريد البابئ.

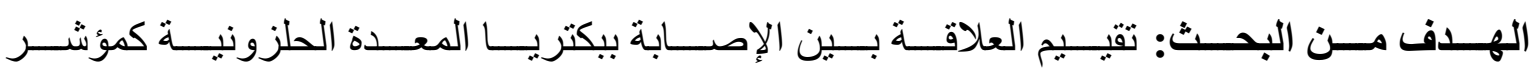
خطورة لنزيف دو الى المرئ و المعدة فى تليف الكبد.

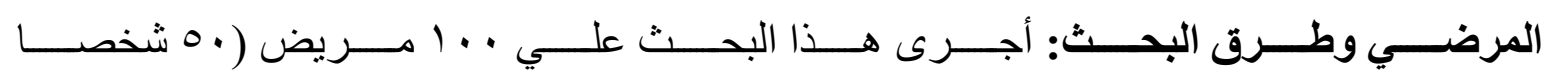

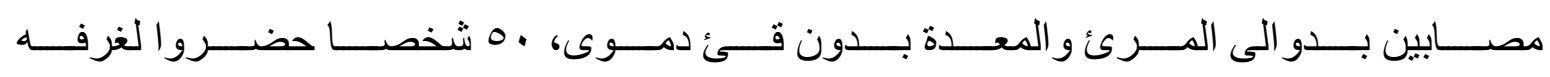

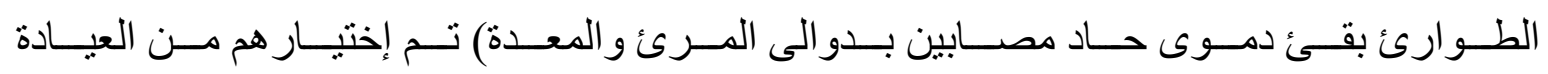

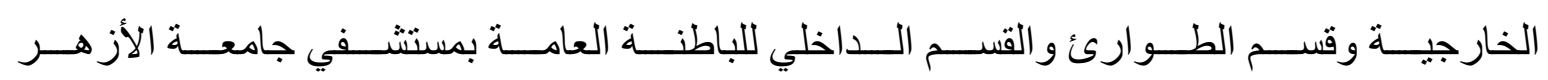

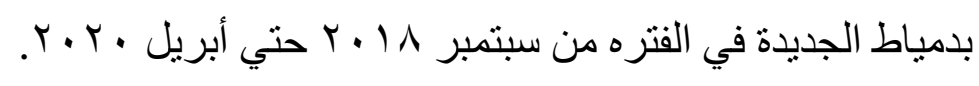
وقد تم تقسيم هؤلاء الأثخاص إلى مجموعتين:

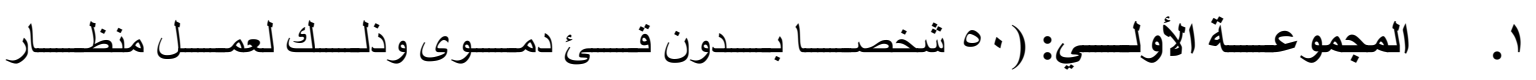

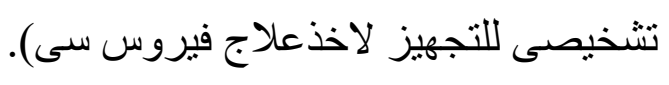

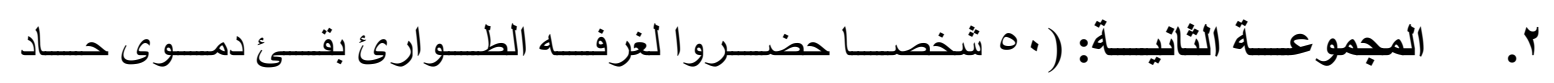
مصابين بدو الى المرئ و المعدة).

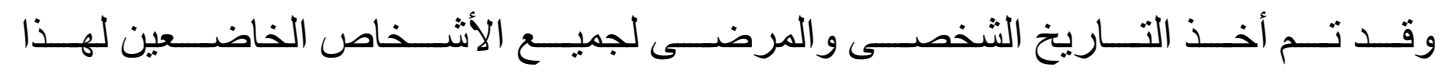

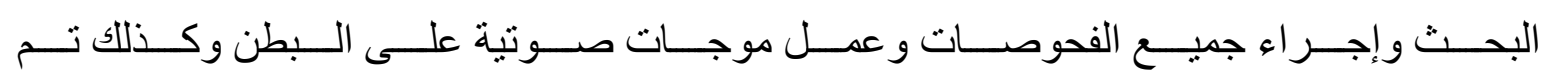
عمل منظار علوى و التحاليل الطبية اللازمة. 


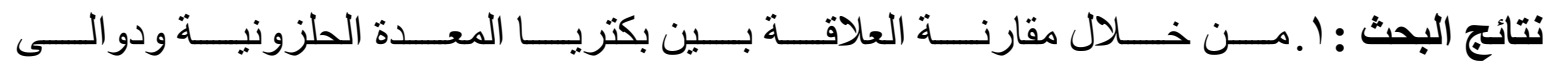

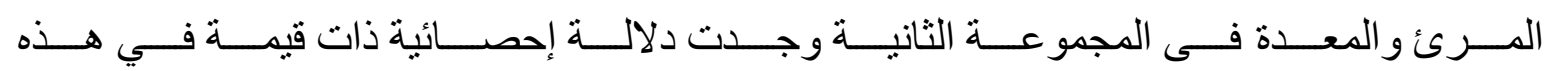

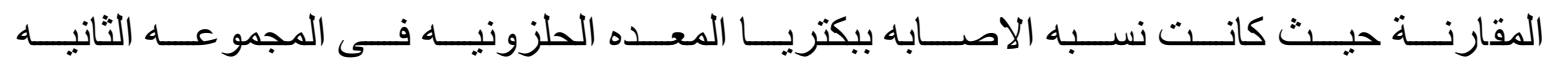

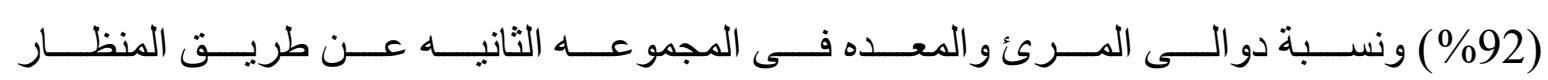

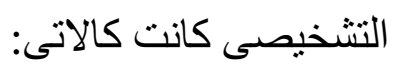

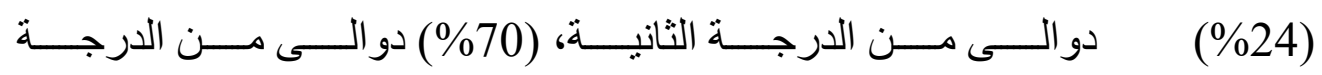

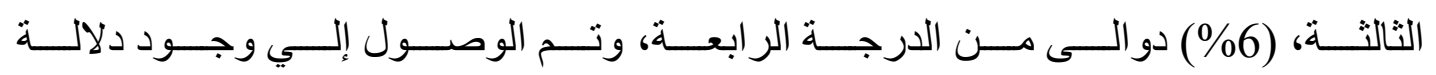

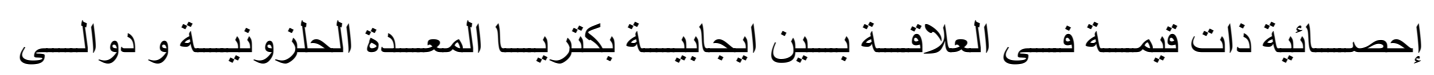
المرئ و المعدة من الدرجة الثالثة.

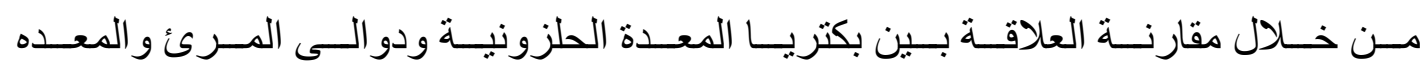
.2

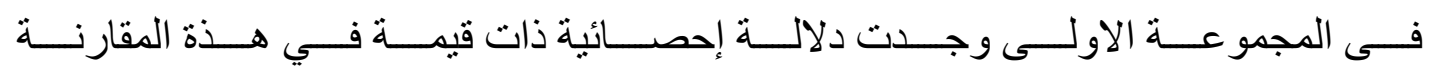

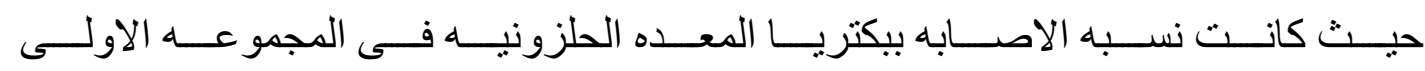

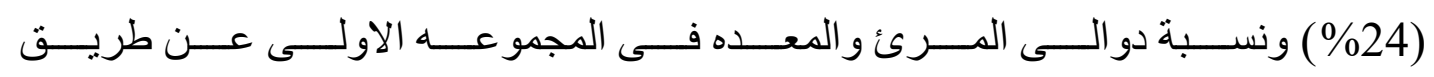

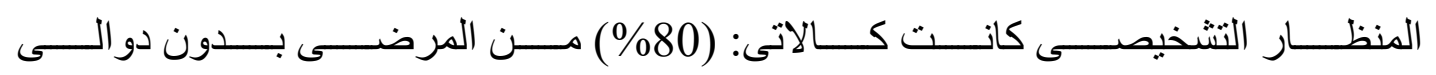

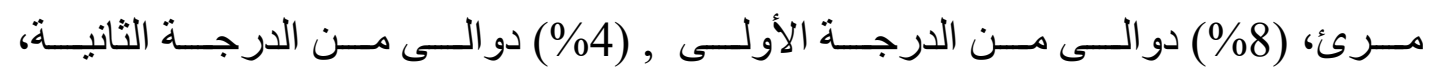

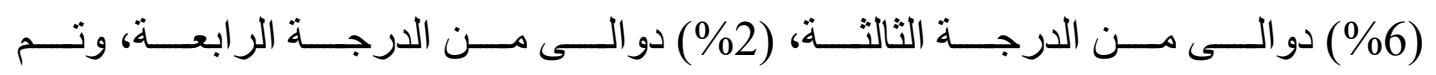

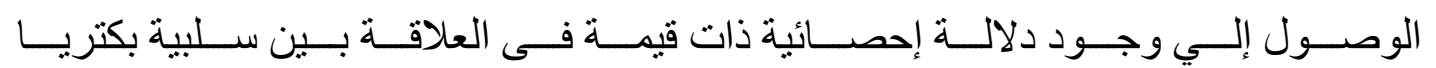
المعدة الحلزونية و عدم وجود دو الى المرئ و المعدة فى المجمو عة الاولى.

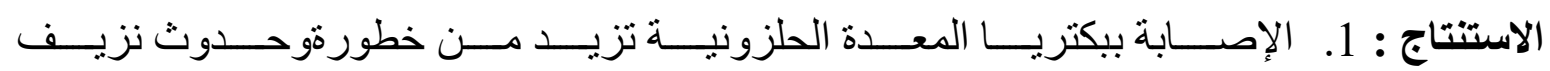

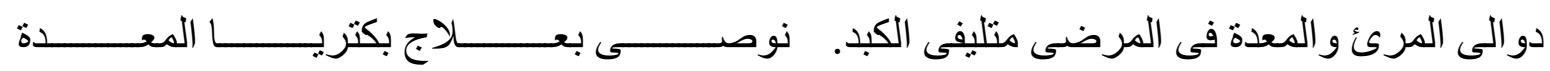
الحلزونية منعا لحدوث وتطور نزيف المرئ و المعدة لمرضى تليف الكبد.

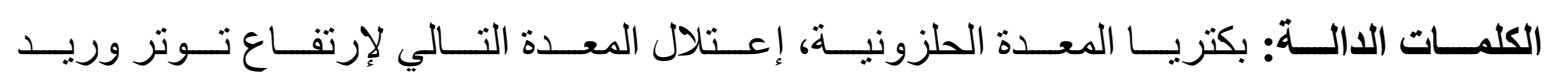
الباب، تليف الكبد، دو الى المرئ و المعدة. 